ISSN 1420-3049

www.mdpi.com/journal/molecules

Review

\title{
Enzyme-Immobilized Microfluidic Process Reactors
}

\section{Yuya Asanomi ${ }^{1}$, Hiroshi Yamaguchi ${ }^{2}$, Masaya Miyazaki ${ }^{1,3,4, *}$ and Hideaki Maeda ${ }^{1,3}$}

1 Measurement Solution Research Center, National Institute of Advanced Industrial Science and Technology (AIST), 807-1 Shuku, Tosu, Saga 841-0052, Japan

2 Liberal Arts Education Center, Aso Campus, Tokai University, Minami-aso, Aso, Kumamoto 869-1404, Japan

3 Department of Molecular and Material Sciences, Interdisciplinary Graduate School of Engineering Science, Kyushu University, 6-1 Kasuga-koen, Kasuga, Fukuoka 816-8580, Japan

4 Department of Advanced Technology Fusion, Graduate School of Science and Engineering, Saga University, 1 Honjo, Saga 840-8502, Japan

* Author to whom correspondence should be addressed; E-Mail: m.miyazaki@aist.go.jp; Tel.: +81-942-81-4059; Fax: +81-942-81-3627.

Received: 24 June 2011; in revised form: 13 July 2011 / Accepted: 17 July 2011 /

Published: 19 July 2011

\begin{abstract}
Microreaction technology, which is an interdisciplinary science and engineering area, has been the focus of different fields of research in the past few years. Several microreactors have been developed. Enzymes are a type of catalyst, which are useful in the production of substance in an environmentally friendly way, and they also have high potential for analytical applications. However, not many enzymatic processes have been commercialized, because of problems in stability of the enzymes, cost, and efficiency of the reactions. Thus, there have been demands for innovation in process engineering, particularly for enzymatic reactions, and microreaction devices represent important tools for the development of enzyme processes. In this review, we summarize the recent advances of microchannel reaction technologies especially for enzyme immobilized microreactors. We discuss the manufacturing process of microreaction devices and the advantages of microreactors compared to conventional reaction devices. Fundamental techniques for enzyme immobilized microreactors and important applications of this multidisciplinary technology are also included in our topics.
\end{abstract}


Keywords: microfluidic reactor; microreactor; immobilization; bioconversion

\section{Introduction}

Microfluidic reaction devices, which can be prepared by microfabrication techniques, or by assembly and modification of microcapillaries, constitute reaction apparatus with small dimensions, large surface to volume ratios and well defined reaction times [1-3]. These systems take advantage of microfluidics or nanofluidics that enables use of micro- or nanoliter volumes of reactant solutions and offer the advantages of high efficiency and repeatability. Therefore, microchannel reaction systems are expected to be the new and promising technology in the fields of chemistry, chemical engineering and biotechnology [4-10]. They offer several advantages over traditional technologies in performing chemical reactions. The key advantages of microsystems include rapid heat exchange and rapid mass transfer that cannot be achieved by the conventional batch system. Unlike macro scale solutions, streams of solutions in a microfluidic system mainly form laminar flow which allows strict control of reaction conditions and time. In addition, microchannel reaction systems provide large surface and interface areas, which are advantageous for many chemical processes such as extractions and catalytic reactions. Several chemical reaction devices have been reported to demonstrate potential applications [4-10]. Moreover, many potential applications for miniaturized synthetic reactors require only small volumes of catalysts.

Enzymatic conversions have recently attracted considerable attention because of their environmentally-friendly nature. Several enzyme processes have been developed; however, improvement of the entire process is still required to obtain the benefits that can be derived from their use and for them to become a common or standard technology [11,12]. Reaction engineering might provide solutions to develop enzyme reaction processes at the commercial level [13], and microreaction engineering is one candidate for such technology. Therefore, several techniques have been developed, either in solution phase or by immobilizing enzymes, to realize enzyme microreaction processes [10,14]. In this review, we summarize recent advances in microchannel reaction technologies, focusing especially on enzyme-immobilized microreactors. We discuss the manufacturing process of microreaction devices and the advantages of microfluidic systems compared to conventional reaction devices. Fundamental techniques for enzyme-immobilized microreactors and important applications of this multidisciplinary technology are also presented.

\section{Microreactor Fundamentals}

For the beginner unfamiliar with microfluidic reaction techniques, we would like to start our review with a brief introduction to microreactors. Microfluidic reactions occur in a small space within a reaction apparatus. Continuous-flow systems are mainly employed, and in most cases mechanical pumping, commonly by syringe pumping, or electroosmotic flow, which is the motion of ions in a solvent environment through very narrow channels, where an applied potential across the channels causes ion migration, are used as the driving force of the reaction systems. Microreaction devices developed so far can be classified into two types: chip-type microreactors and microcapillary devices. 
Chip-type microreactors which offer several advantages, including easy control of microfluidics, and integration of many processes into one reaction device. Chip-type microreactors have been mainly used for the development of bioanalytical devices. The manufacturing processes of such devices were adapted mainly from the microelectronics industry. Dry-or wet-etching processes have been used for creating channels on a silicone or glass plates. Polymer-based materials can be used for preparation of enzyme microreactors because most enzyme reactions are performed in aqueous solution, especially for bioanalytical use. Polydimethylsiloxane (PDMS), polymethylmethacrylate (PMMA), polycarbonate, and Teflon were used for preparation of microreaction devices. These plates could be processed by photolithography, soft lithography, injection molding, embossing, and micromachining with lasers or microdrilling. The LIGA (Lithographic Galvanoforming Abforming) process which consists of a combination of lithography, electrochemical technology and molding, can also be used for the production of microreactors.

In a microreactor, stable formation of laminar streams of different solutions is sometimes required, although some cases require better mixing by disrupting laminar streams. Methods for stabilizing multiple laminar flows and micromixing have been developed. Tokeshi et al. developed guide structures at the bottom of microchannels [15]. The structures were prepared by wet etching of a glass plate. Laminar streams of organic solvent and water in these microchannels were stabilized by these guide structures. Techniques for partial surface modification of microchannels were also developed. These techniques take advantage of the different surface properties. Organic solvents prefer hydrophobic regions, whereas aqueous solutions go to hydrophilic regions. Modification of glass by octadesylsilane was used to stabilize the flow of organic solvent and aqueous solutions [16]. In another study, a UV-sensitive self-assembled monolayer with fluorous chains was used for preparing partially-modified microchannel surfaces [17]. Our laboratory developed another method to stabilize solutions [18]. Microchannels were fabricated on both bottom and top plates. The microchannels of one of the two plates were coated with gold, then treated with alkanethiol to produce a hydrophobic surface. The resulting microreactor, which forms an upside-down laminar stream, was not only stabilized by interaction with surface, but also supported by gravity. Overall, such partial modification methods are useful to stabilize laminar streams under pressure below the critical value. Indeed, microfluidic phenomenon of laminar flow is one important aspect in the development of chip-type microreactors.

Micromixers which enhance mixing of two or more different solutions in microspace have also been constructed. Rapid mixing in microfluidics is difficult to achieve because under laminar flow mixing of fluids is principally limited to diffusion through the interface. Several micromixers were developed by adding devices or materials in the microchannel, such as electrokinetical mixing [19] and microbeads [20]. Various types of micromixers which only require structured microchannels were also developed. These include chaotic mixers with oriented ridges at the bottom of microchannels [21], repeated dividing and merging of fluids with a two-way separated serpentine flow path [22], zig-zag microchannels [23], and simple convergence to 32 layers with two solutions divided into 16 microchannels [24]. Detail of micromixing can be found in recent reviews [25]. Still, design and fabrication of highly efficient micromixers for effective functioning of microfluidic devices are desired research topics. 
The other type of microreaction device consists of microcapillaries. This is the simplest method which does not require any control of microfluidics, rather, it uses a microchannel as the reaction space. The major advantage of this type of microreactors is in scaling up process which can be achieved by simply bundling more microcapillaries. Gas or liquid chromatography parts are chiefly used to prepare this type of microreactors. Capillary type microreactors are mainly used to develop manufacturing processes, especially catalytic reactions, to take advantage of the large surface area. The users should select the type of microreactor depending on the feature of reaction which they want to perform in a microreactor.

\section{Fundamental Techniques for Enzyme Immobilized Microreactor}

\subsection{Enzyme-Immobilization within Microchannels}

In the development of enzyme processes, the use of immobilized enzymes is preferable. Several methods have been used to immobilize enzymes on supports in conventional reaction apparatus, and these techniques have also been applied to immobilize enzyme within a microspace (Tables 1-3).

Table 1. Enzyme-immobilization within microchannel reactors by particle entrapment techniques.

\begin{tabular}{|c|c|c|c|c|}
\hline Media & Immobilization method & Enzyme & Advantage and disadvantage & Ref. \\
\hline Glass & $\begin{array}{l}\text { Cross-linking } \\
\text { (3-aminopropylsilane/ } \\
\text { glutaraldehyde) }\end{array}$ & $\begin{array}{l}\text { Xantin oxidase } \\
\text { Horseradish } \\
\text { peroxidase }\end{array}$ & $\begin{array}{l}\text { Ease in preparation } \\
\text { Enable multistep reaction } \\
\text { Limited number of enzymes are applicable due } \\
\text { to denaturation } \\
\text { Pressure gain }\end{array}$ & {$[26]$} \\
\hline Polystyrene & $\begin{array}{l}\text { Biotin-Avidin (Avidin- } \\
\text { coated beads were used) }\end{array}$ & $\begin{array}{l}\text { Horseradish } \\
\text { peroxidase }\end{array}$ & \begin{tabular}{|l} 
Ease in preparation \\
Enable multistep reaction \\
Biotin-label is required \\
Pressure gain
\end{tabular} & {$[20]$} \\
\hline Agarose & $\begin{array}{l}\text { Complex formation } \\
\text { (Ni-NTA and His-tag) }\end{array}$ & $\begin{array}{l}\text { Horseradish } \\
\text { peroxidase }\end{array}$ & $\begin{array}{l}\text { Ease in preparation } \\
\text { Applicable for engineered enzymes } \\
\text { Higher pressure by increasing flow rate and } \\
\text { particles may be crushed }\end{array}$ & {$[27]$} \\
\hline Polystyrene & $\begin{array}{l}\text { Complex formation } \\
\text { (Ni-NTA and His-tag) }\end{array}$ & Glucose oxidase & $\begin{array}{l}\text { Ease in preparation } \\
\text { Applicable for engineered enzymes } \\
\text { Higher pressure by increasing flow rate and } \\
\text { particles may be crushed }\end{array}$ & {$[28]$} \\
\hline $\begin{array}{l}\text { Magnetic } \\
\text { bead }\end{array}$ & $\begin{array}{l}\text { Cross-linking } \\
\text { (3-aminopropylsilane/ } \\
\text { glutaraldehyde) }\end{array}$ & Bacterial P450 & $\begin{array}{l}\text { Preparation is easy } \\
\text { Enzyme can be immobilized on any place by } \\
\text { placing a magnet } \\
\text { Amount of enzyme particle is limited because of } \\
\text { plugging }\end{array}$ & {$[29,30]$} \\
\hline $\begin{array}{l}\text { Polymer } \\
\text { monolith }\end{array}$ & $\begin{array}{l}\text { Entrapment(2-vinyl-4,4- } \\
\text { dimethylazlactone, } \\
\text { ethylenedimethacrylate, } \\
\text { 2-hydroxyethyl } \\
\text { methacrylate, acrylamide) }\end{array}$ & Benzaldehyde liase & $\begin{array}{l}\text { Stabilization of enzyme structure and activity } \\
\text { Requirement of skill in preparation } \\
\text { Denaturation during entrapment process }\end{array}$ & {$[31]$} \\
\hline $\begin{array}{l}\text { Silica } \\
\text { monolith }\end{array}$ & $\begin{array}{l}\text { Entrapment within porous } \\
\text { silica }\end{array}$ & $\begin{array}{l}p \text {-Nitrobenzyl } \\
\text { esterase }\end{array}$ & $\begin{array}{l}\text { Stabilization of enzyme structure and activity } \\
\text { Compatibility in organic solvent } \\
\text { Requirement of skill in preparation } \\
\text { Denaturation possible during entrapment } \\
\text { process }\end{array}$ & $\begin{array}{l}{[32,33,} \\
35]\end{array}$ \\
\hline
\end{tabular}


Table 1. Cont.

\begin{tabular}{|l|l|l|l|l|}
\hline $\begin{array}{l}\text { Aluminium } \\
\text { oxide }\end{array}$ & $\begin{array}{l}\text { Cross-linking } \\
\text { (3-aminopropylsilane/ } \\
\text { glutaraldehyde })\end{array}$ & Glucose oxidase & $\begin{array}{l}\text { Large surface area due to porous nature } \\
\text { Applicable for heterogeneous reactions } \\
\text { Complicated preparation } \\
\text { Not applicable for large-scale processing }\end{array}$ & {$[34]$} \\
\hline $\begin{array}{l}\text { Porous } \\
\text { polymer } \\
\text { monolith }\end{array}$ & Multistep photografting & $\begin{array}{l}\text { Trypsin } \\
\text { LysC }\end{array}$ & $\begin{array}{l}\text { Eliminate nonspecific adsorption of proteins and } \\
\text { peptides }\end{array}$ & {$[36]$} \\
\hline $\begin{array}{l}\text { CIM-disk } \\
\text { epoxy } \\
\text { monolith }\end{array}$ & Entrapment within monolith & Glycosyltransferases & $\begin{array}{l}\text { CIM }^{\circledR} \text { Epoxy Disk Monolithic Column is } \\
\text { available for purchase }\end{array}$ & {$[37]$} \\
\hline $\begin{array}{l}\text { Caged } \\
\text { mesoporous } \\
\text { silica in } \\
\begin{array}{l}\text { Ca- alginate } \\
\text { fiber }\end{array}\end{array}$ & $\begin{array}{l}\text { Entrapment within amine- } \\
\text { modified mesoporous silica }\end{array}$ & Glucose oxidase & $\begin{array}{l}\text { Reduced leakage and improved activity and } \\
\text { stability of the immobilized enzyme }\end{array}$ & {$[38]$} \\
$\begin{array}{l}\text { LTCC } \\
\text { multilayer } \\
\text { substrates }\end{array}$ & $\begin{array}{l}\text { Cross-linking } \\
\text { (Glyoxal-agarose gels })\end{array}$ & $\beta$-galactosidase & Stable operation for 6 months & {$[39]$} \\
\hline
\end{tabular}

Table 2. Typical techniques for enzyme-immobilization on microchannel surfaces.

\begin{tabular}{|c|c|c|c|c|}
\hline Media & Immobilization method & Enzyme & Advantage and disadvantage & Ref. \\
\hline $\mathrm{SiO}_{2}$ surface & $\begin{array}{l}\text { Physical adsorption of } \\
\text { biotinylated poly-lysine } \\
\text { /biotin-avidin }\end{array}$ & Alkaline phosphatase & $\begin{array}{l}\text { Ease in preparation } \\
\text { Requirement for avidin-conjugation } \\
\text { Possible occurrence of detachment }\end{array}$ & {$[40]$} \\
\hline $\begin{array}{l}\mathrm{PDMS}\left(\mathrm{O}_{2}\right. \\
\text { Plasma } \\
\text { treated })\end{array}$ & $\begin{array}{l}\text { Physical adsorption of lipid } \\
\text { bilayer/biotin-avidin }\end{array}$ & Alkaline phosphatase & $\begin{array}{l}\text { Enable immobilization of enzyme on plastic } \\
\text { surface } \\
\text { Possible occurrence of detachment } \\
\text { Expensive reagents } \\
\text { Requirement for avidin-conjugation }\end{array}$ & {$[41]$} \\
\hline PDMS & $\begin{array}{l}\text { Physical adsorption of } \\
\text { fibrinogen/Photochemical } \\
\text { reaction of Fluorescein- } \\
\text { biotin }\end{array}$ & Alkaline phosphatase & $\begin{array}{l}\text { Enable partial modification of microchannel } \\
\text { Special equipment is required }\end{array}$ & {$[42]$} \\
\hline Silicon & $\begin{array}{l}\text { Cross-linking } \\
\text { (3-aminopropylsilane/ } \\
\text { glutaraldehyde) }\end{array}$ & Trypsin & $\begin{array}{l}\text { Simple operation } \\
\text { Difficulty in channel preparation } \\
\text { Poor reproducibility }\end{array}$ & {$[43]$} \\
\hline $\begin{array}{l}\text { Fused silica } \\
\text { (Sol-gel } \\
\text { modified) }\end{array}$ & $\begin{array}{l}\text { Cross-linking } \\
\text { (3-aminopropylsilane/ } \\
\text { glutaraldehyde) }\end{array}$ & $\begin{array}{l}\text { Cucumisin } \\
\text { Lipase } \\
\text { L-Lactic } \\
\text { dehydrogenase }\end{array}$ & \begin{tabular}{|l|} 
Simple operation \\
Immobilize $\sim 10$ times more enzymes than single \\
layer immobilization and therefore, performs \\
with higher reaction efficiency \\
Several chemistry is available (amide, disulfide, \\
His-tag) \\
Needs several steps for immobilization \\
Reproducibility strongly affected by \\
characteristics of silica surface
\end{tabular} & {$[44-47]$} \\
\hline PMMA & $\begin{array}{l}\text { Cross-linking ( } \mathrm{Si}-\mathrm{O} \text { bond } \\
\text { between modified surface } \\
\text { and silica monolith) }\end{array}$ & Trypsin & $\begin{array}{l}\text { Stabilize enzyme under denaturation condition } \\
\text { Complicated preparation method }\end{array}$ & {$[48]$} \\
\hline $\begin{array}{l}\text { PDMS } \\
\left(\mathrm{O}_{2} \text { Plasma }\right. \\
\text { treated })\end{array}$ & $\begin{array}{l}\text { Cross-linking ( } \mathrm{Si}-\mathrm{O}-\mathrm{Ti} \text { or } \\
\text { Si-O-Al bond between } \\
\text { titania or alumina monolith) }\end{array}$ & Trypsin & $\begin{array}{l}\text { Stabilizes enzyme under denaturation condition } \\
\text { Complicated preparation method }\end{array}$ & {$[49]$} \\
\hline $\begin{array}{l}\text { PET } \\
\text { microchip }\end{array}$ & $\begin{array}{l}\text { Entrapment within } \\
\text { nanozeolite-assembled } \\
\text { network }\end{array}$ & Trypsin & $\begin{array}{l}\text { Large surface/volume network by layer-by-layer } \\
\text { technique }\end{array}$ & {$[50]$} \\
\hline
\end{tabular}


Table 2. Cont.

\begin{tabular}{|c|c|c|c|c|}
\hline Silicon rubber & $\begin{array}{l}\text { Cross-linking (3- } \\
\text { aminopropyltrieth-oxysilane } \\
\text { and glutaraldehyde) }\end{array}$ & $\begin{array}{l}\text { Thermophilic } \\
\beta \text { - glycosidase }\end{array}$ & $\begin{array}{l}\text { Reaction can be performed at } 80^{\circ} \mathrm{C} \\
\text { Complicated preparation method } \\
\text { Reaction is slow because not much enzyme can } \\
\text { be immobilized }\end{array}$ & [51] \\
\hline Fused silica & $\begin{array}{l}\text { Cross-linking between } \\
\text { physically-immobilized } \\
\text { Silica particle } \\
\text { (3-aminopropylsilane/ } \\
\text { succinate) }\end{array}$ & Lipase & $\begin{array}{l}\text { Much larger surface area (1.5 times greater than } \\
\text { sol-gel modified surface) and higher efficiency } \\
\text { Complicated preparation method } \\
\text { Unstable withed physical force (bending etc.) }\end{array}$ & {$[52]$} \\
\hline $\begin{array}{l}\mathrm{SiO}_{2} \\
\text { nanospring }\end{array}$ & Disulfide bond & $\beta$-galactosidase & $\begin{array}{l}\text { High solvent-accessible surface area } \\
\text { permeability and mechanical stability } \\
\text { Repeatability of re-immobilization was poor }\end{array}$ & {$[53]$} \\
\hline $\begin{array}{l}\text { Photopatternin } \\
\text { g onto PEG- } \\
\text { grafted surface }\end{array}$ & $\begin{array}{l}\text { Cross-linking by photo- } \\
\text { patterned vinylazlactone }\end{array}$ & $\begin{array}{l}\text { Horseradish } \\
\text { peroxidase } \\
\text { Glucose oxidase }\end{array}$ & $\begin{array}{l}\text { Reduced non-specific absorption } \\
\text { Sequentially multistep reaction could be } \\
\text { achieved } \\
\text { Requires special equipment }\end{array}$ & [54] \\
\hline PDMS & $\begin{array}{l}\text { Entrapment within hydrogel } \\
\text { formed on surface }\end{array}$ & $\begin{array}{l}\text { Alkaline phosphatase } \\
\text { Urease }\end{array}$ & $\begin{array}{l}\text { Quite fast reaction }(90 \% \text { conversion at } 10 \mathrm{~min} \\
\text { reaction) } \\
\text { Immobilization of multiple enzyme } \\
\text { Complicated preparation method } \\
\text { Not applicable for higher flow rate }\end{array}$ & [55] \\
\hline
\end{tabular}

Table 3. Enzyme-immobilization techniques on a membrane.

\begin{tabular}{|c|l|l|l|c|}
\hline Media & \multicolumn{1}{|c|}{ Immobilization method } & \multicolumn{1}{c|}{ Enzyme } & \multicolumn{1}{c|}{ Advantage and disadvantage } & Ref. \\
\hline PDMS/Glass & $\begin{array}{l}\text { Place PVDF membrane that } \\
\text { adsorbs enzymes }\end{array}$ & Trypsin & $\begin{array}{l}\text { Easy preparation } \\
\text { Less efficiency } \\
\text { Possibility of leakage at higher flow rate }\end{array}$ & {$[56]$} \\
\hline Glass & $\begin{array}{l}\text { Covalent cross-linking with } \\
\text { Nylon membrane formed at } \\
\text { liquid-liquid interface } \\
\text { glutaraldehyde) }\end{array}$ & $\begin{array}{l}\text { Horseradish } \\
\text { peroxidase }\end{array}$ & $\begin{array}{l}\text { Integration of membrane permeation and } \\
\text { enzyme reaction } \\
\text { Preparation of multiple membrane } \\
\text { Complicated preparation method } \\
\text { Unstable membrane at higher flow rat }\end{array}$ & {$[57]$} \\
\hline PTFE & $\begin{array}{l}\text { Enzyme-embedded } \\
\text { membrane formation using } \\
\text { glutaraldehyde/ } \\
\text { paraformaldehyde }\end{array}$ & $\begin{array}{l}\alpha \text {-Chimotrypsin } \\
\text { Trypsin } \\
\alpha \text {-Aminoacylase } \\
\text { Other various } \\
\text { enzymes }\end{array}$ & $\begin{array}{l}\text { Easy preparation } \\
\text { Durable (>40days) } \\
\text { Applicable in organic solvents } \\
\text { Almost all enzymes can be immobilized by } \\
\text { adding poly-Lys }\end{array}$ & {$[58-60]$} \\
\hline
\end{tabular}

In batchwise reactors, immobilization of enzymes on beads or monoliths has been used for separation and recycling of enzymes. This approach has also been applied to microreaction systems. Microreactors with enzymes immobilized on glass beads have been prepared by simply filling the reaction chamber with enzyme-immobilized particles. Such a device was used for the determination of xanthine using chemiluminescent detection [26]. Crooks and co-workers developed advanced analytical microreactors using enzyme-immobilized microbead-mixing [20], and efficiently performed multistep enzyme reactions using glucose oxidase- and horseradish peroxidase-immobilized polystyrene. In addition, immobilization of enzyme on Ni-NTA-agarose bead has also been reported [27]. This immobilized enzyme is less denaturated because binding of the enzyme is achieved using a His-tag. This method was applied to immobilize bacterial $\mathrm{P}_{450}$ [27]. A similar approach was applied to immobilize enzymes onto a Merrifield resin [28]. A tyrosine-based Ni-NTA linker was created on the surface of the resin to immobilize His-tagged enzymes. This matrix was loaded into a microstructured 
channel of a PASSflow ${ }^{\mathrm{TM}}$ system. Synthesis of $(R)$-benzoin, $(R)$-2-hydroxy-1-phenylpropan-1-one, and 6-O-acetyl-D-glucal were performed using this system. Magnetic beads were also used for enzyme immobilization within the microchannel. Glucose oxidase was immobilized within a Teflon tube by placing a magnet [29]. The enzyme-immobilized magnetic particles were stable and active for more than eight months. This approach was also applied for the preparation of a protease-immobilized microreactor for proteomic analysis [30]. A similar technique was used for preparation of enzymeimmobilized microfluidic reactors.

Monolithic microreactors can be prepared using several methods. A trypsin-immobilized microreactor was prepared by molding a porous polymer monolith, prepared from 2-vinyl-4,4dimethylazlactone, ethylene dimethacrylate, and acrylamide or 2-hydroxyethyl methacrylate, with an enzyme, in microchannels [31]. This microreactor was used for mapping protein digested fragments. Preparation of a microreactor by filling a silica monolith made from tetraethoxysilane with an enzyme and entrapping it within a microchannel was also developed. Trypsin-encapsulated monolith was fabricated in situ on a PMMA microchip to produce an integrated bioreactor that can perform enzymatic digestion, electrophoretic separation and detection in one chip [32]. Another example is a protease-P-including monolith prepared from a mixture of tetramethoxysilane and methyltrimethoxysilane (1:4), used to fill in PEEK [poly(ether ether ketone)] microcapillary to produce a microreaction system [33]. Aluminum oxide powder can be used as a solid support. Horseradish peroxidase was immobilized on aluminium oxide with 3-aminopropylsilane, and then placed within the microdevice [34]. This method takes advantage of the porous nature of ceramic microstructures. Overall, preparation of immobilized enzymes with powdered materials or monoliths is significantly easier; however it is unfavorable in large scale processing because of increasing pressure.

\subsection{Immobilization of Enzyme on Microchannel Surface}

Methods for enzyme immobilization on the microchannel surface have also been developed because they can take advantage of the larger surface area of microreaction systems without pressure increases. Physical immobilization is an easy way to immobilize molecules. In microchannel systems, a biotin-avidin system has mainly been used to immobilize enzymes. The biotinylated polylysine was physically immobilized on a glass surface to immobilize streptavidin-conjugated alkaline phosphatase [40]. This microreactor was used for rapid determination of enzyme kinetics. Biotinylated lipid bilayer [41] and partial biotinylation by photo patterning on fibrinogen [42] were also used for immobilization. However, these methods are not suitable for long-term use because of their instability. Also, applications are limited to streptavidin-conjugated enzymes.

The introduction of a functional group on the microchannel surface was used for covalent crosslinking. A trypsin-immobilized microreactor was prepared by modification with 3-aminopropylsilane and glutaraldehyde using the classical method [43]. Although this immobilization method is easy, fabrication of complex microstructures is required to achieve high performance. Our group developed a modified sol-gel technique to form nanostructures on a silica microchannel surface [44]. This method modifies the microchannel surface with polymerized copolymer of 3-aminopropylsilane/methylsilane. Using this method, increased surface area was obtained. At least 10 times more enzymes can be immobilized on these nanostructures by covalent cross-linking through amide-bond formation, 
disulfide or His-tag, by modifying succinate spacer, compared with single layer immobilization [4547]. A microreactor with immobilized cucumisin on the nanostructured surface could process substrate 15 times faster than the corresponding batchwise reaction [46].

Similar surface modification methods employing sol-gel techniques were also developed [48]. A PMMA surface was modified with a copolymer of butyl methacrylate/ $\gamma$-(methylacryloxy)propyltrimethoxysilicane and silica-sol-gel to immobilize enzymes. Using this method, a trypsinimmobilized microreactor was developed. In addition, a trypsin-encapsulated titania and alumina gel matrix was immobilized through $\mathrm{SiOH}$ group formed on a PDMS surface by plasma oxidation [49]. Using this device, digestion time was significantly shortened (ca. 2 s) and the application for highthroughput protein identification was realized. Ji et al. developed the layer-by-layer nanozeoliteassembled network to immobilize enzymes in the porous structure formed within zeolite (Figure 1a) [50]. Alternatively, silicone rubber material was used for the preparation of functional nanostructure on the microchannel surface (Figure 1b) [51].

Figure 1. Images of surface modification and membrane formation techniques for micro enzyme reactor. Modified surface obtained by functionalized microstructure fabricated from layer-by-layer nanozeolite-assembled network (a), silicone rubber (b), nanoparticle arrangement (c), $\mathrm{SiO}_{2}$ nanospring structures (d), and hydrogel formation (e). Membrane formed within the microchannel can also be used as support for enzyme immobilization. Nylon membrane formed at liquid-liquid interface (f), or membrane of cross-linking enzyme aggregate formed at microchannel surface (g) was used for immobilization. These images were reproduced with permission from references [50,51,53,55,57,58,61].

(a)

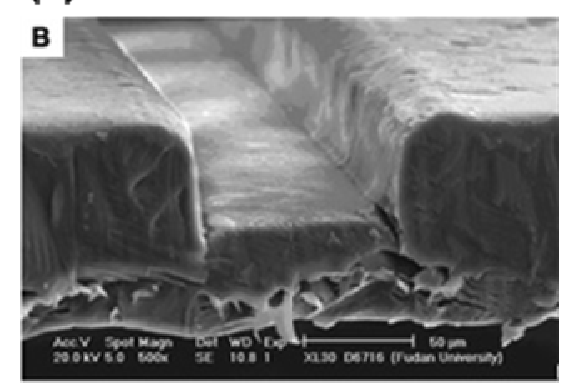

(b)

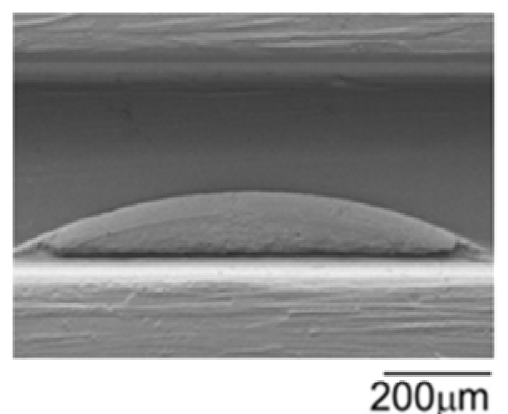

(c)

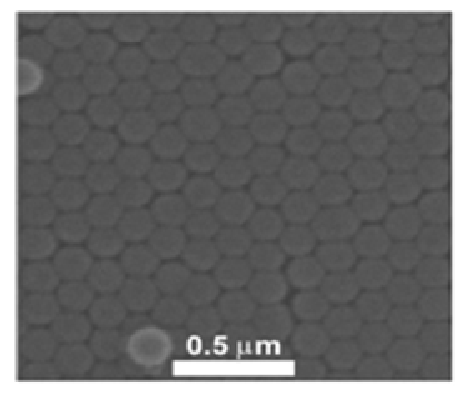

(d)

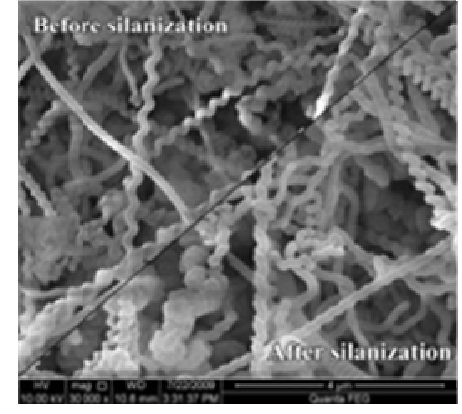

(e)

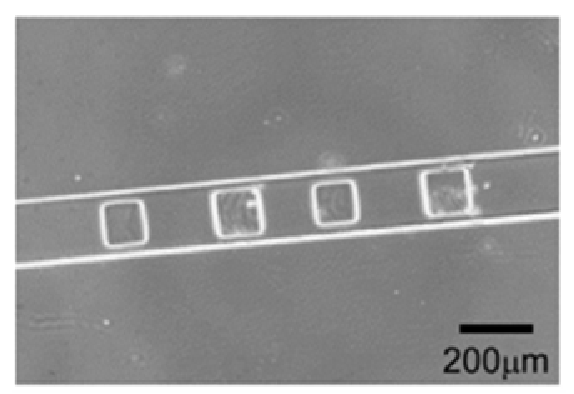


Figure 1. Cont.
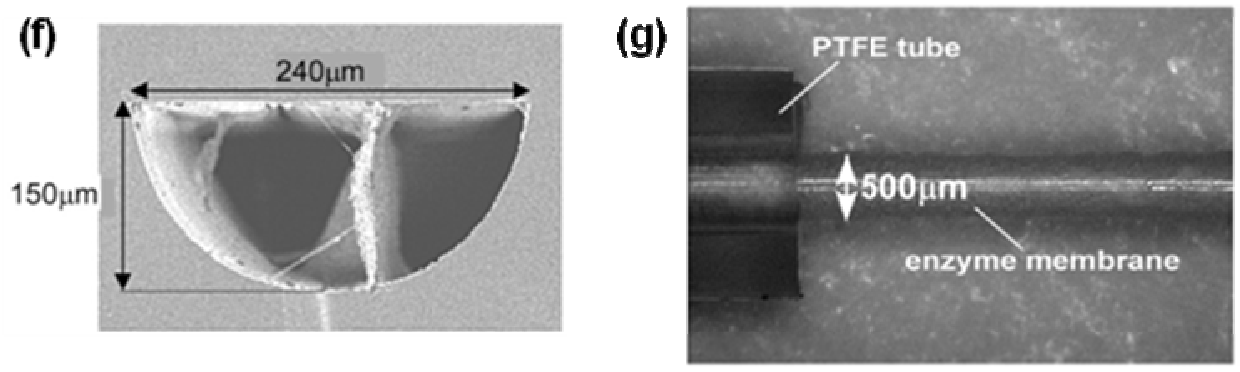

The structure was prepared by micromold fabrication using vinyl-group-containing PDMS and silicic acid, and enzyme immobilization by cross-linking with glutaraldehyde. Using this procedure, a microstructured enzyme reactor with immobilized thermophilic $\beta$-glycosidase capable of performing hydrolysis at $80{ }^{\circ} \mathrm{C}$ was created. A particle-arrangement technique was also applied for enzyme immobilization. Silica nanoparticles were immobilized onto the surface using slow evaporation of particle suspension filled-in microchannel (Figure 1c) [61]. The obtained microchannel was subjected to treatment with 3-aminopropyltriethoxysilane, and immobilization of enzyme was achieved by covalent cross-linking through the amino groups. Although physical stability needs to be improved, a lipase-immobilized microreactor prepared by this method showed 1.5 times faster kinetics than that of microreactor obtained by sol-gel surface modification [52]. This result showed good correlation with the surface area; particle arrangement has approximately 1.5 times larger surface area and could immobilize more enzymes. A $\mathrm{SiO}_{2}$ nanospring structure formed by chemical vapor deposition was also used as immobilization supports. (Figure 1d) [53]. Photochemistry has been applied to enable selective immobilization of enzymes on the microchannel surface [54]. In the procedure, vinyl azlactone was photografted onto a PEG-coated polymer surface as a reactive monomer and the enzymes were immobilized through their amino groups. This approach was applied for immobilization of horseradish peroxidase. Another approach for efficient enzyme immobilization is polymer coating. Poly(ethylene glycol)based-hydrogels which incorporate alkaline phosphatase was prepared within a microchannel by exposure to UV light (Figure 1e) [55]. This method was also applied to immobilize urease and different enzymes on microchannel surfaces. Overall, these techniques need expensive equipments and/or specialized fabrication skills.

\subsection{Membrane-Formation}

Enzymes can be immobilized on a membrane within the microchannel. A porous poly(vinylidene fluoride) membranes embedded within microchannel can be used for enzyme immobilization. Preparation of a miniaturized membrane reactor by absorption of enzymes onto the membrane has been reported [56].

Hisamoto et al. demonstrated that a nylon-membrane formation at the interface of two solutions formed in a microchannel (Figure 1f). Peroxidase was immobilized on this membrane which was then used as a chemicofunctional membrane [57]; however, immobilization of the membrane is technically difficult, and application of this method is limited because the nylon-membrane is unstable in organic solvents. 
We have developed a technique that forms an enzyme-immobilizing membrane on the microchannel surface [58]. This is a modification of cross-linked enzyme aggregate (CLEA) formation, which is used in batchwise organic synthesis [62]. Simple loading of the enzyme solution and a mixture of glutaraldehyde and paraformaldehyde into the microchannel forms a CLEA membrane on the microchannel wall (Figure $1 \mathrm{~g}$ ). The resulting microreactor can be used for prolonged periods ( $>40$ days), and shows excellent stability against organic solvents. Taking into account these advantages, this method is considered ideal for the development of an enzymatic reactor tailored for specific applications. However, this method requires amino groups for immobilization, and is difficult to apply to acidic enzymes with few amino groups on their surface. The application of the approach developed in our laboratory was expanded by adding poly-Lys to aid in membrane formation of acidic proteins [59]. By this method, almost all enzymes, including highly acidic proteins, can form crosslinked aggregates. We applied this technique for the preparation of enzyme microreactors, and demonstrated immobilization of several acidic enzymes by this method [59]. Our results indicate that almost all enzymes can be immobilized onto the microchannel surface by our method, and our approach is a robust way of enzyme-immobilized microreactor development.

\section{Enzyme-Immobilized Microfluidic Reactor Processes}

\subsection{Hydrolysis and Esterification}

Applications of enzyme-immobilized microreactors for processing for several important reactions in the synthetic organic chemistry field have been reported. As shown in Table 4, esterification and hydrolysis reactions are important processes in the industry that have also been performed in a microchannel system. Lipase-immobilized microreactors were prepared using a ceramic microreactor and glass microcapillaries [45], wherein hydrolysis of the ester was conducted. Both microreactors showed 1.5 times better yield than the batchwise reaction using the same volume/enzyme ratios. This could have resulted from an increase in contact due to the larger surface area of the microchannel systems. Hydrolysis of triglyceride using a lipase-immobilized microreactor was also reported. The reaction yield was 10 times higher than that of the corresponding batchwise reaction [63]. Hydrolysis of vegetable oil to produce monoacyl glycerol was performed in an immobilized lipase microreactor [64]. Almost complete conversion was enabled by the microreaction system. Not only hydrolysis, but esterifications were also performed in microfluidic format. A microreaction using immobilized Novozym- $435^{\mathrm{TM}}$ was also reported, where esterification of diglycerol with lauric acid was performed [65].

Esterases are also used as catalysts to produce esters and their hydrolysis products. Dräger et al. reported a regioselective hydrolysis reaction by $p$-nitrobenzyl esterase immobilized onto Ni-NTA agarose beads entrapped within microchannels [28]. Although an $80 \%$ yield was obtained with the microreactor, trace by-products were also detected. Proteases and aminoacylases are important tools for the preparation of chiral compounds. A monolithic microreactor tethered protease P was applied for bioconversion processes. Transesterification of (S)-(-)-glycidol and vinyl $n$-butyrate was performed using this microreaction device [33], but the conversion depended on the amount of immobilized enzymes. 
Table 4. The use of enzyme-immobilized microreactors for hydrolysis and esterification.

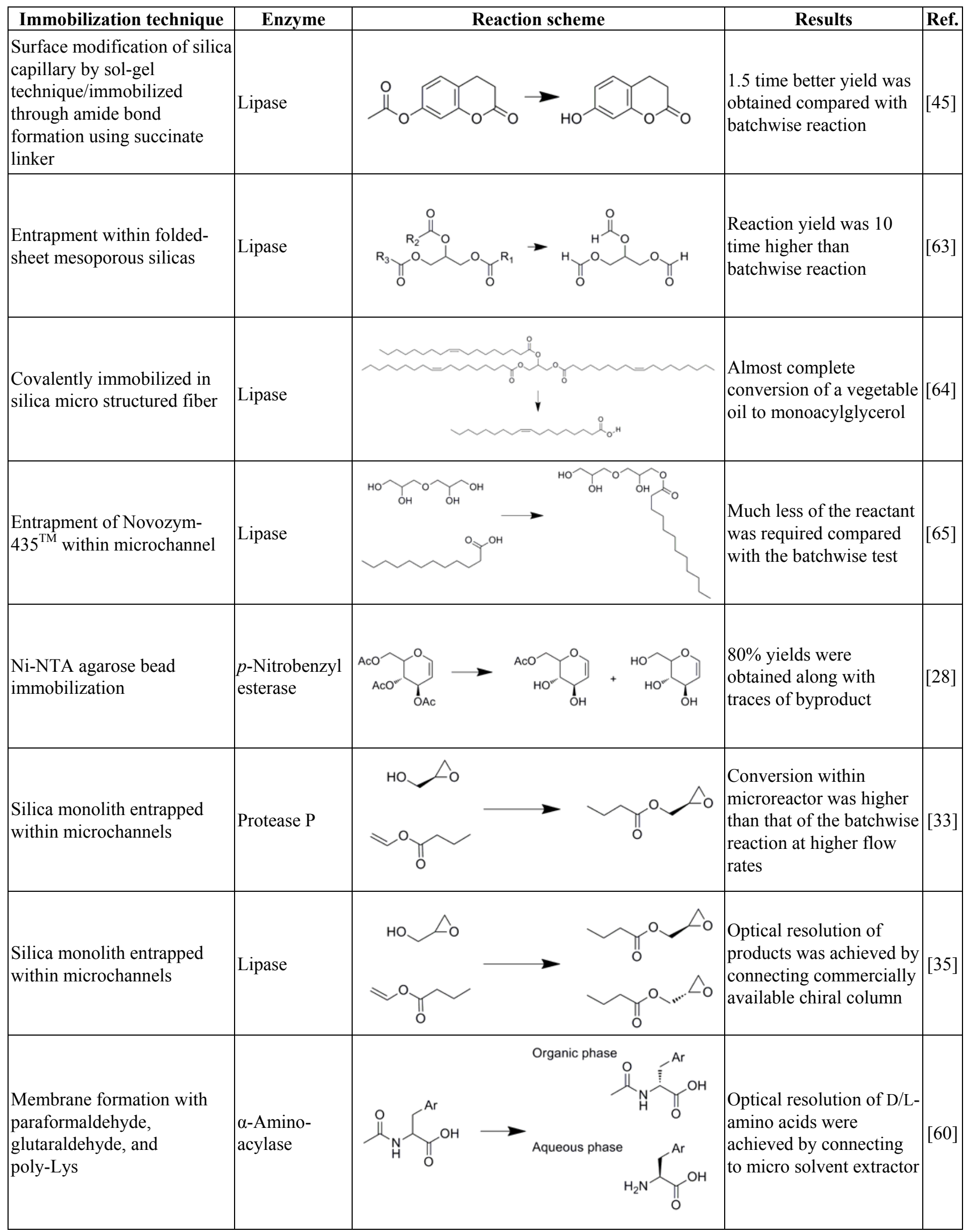


Similarly, they separated the racemic product which was obtained by reaction in an entrapped lipase microreactor, by connecting a chiral column sequentially to the microreactor [35]. We developed a novel integrated microreaction system which combined an enzyme microreactor and a solvent extractor. The enzyme-immobilized microreactor was prepared by the membrane-formation technique using $\alpha$-aminoacylase with poly-Lys [59]. This microreactor was connected with a microextractor which has a partially modified microchannel [18]. Using this microreaction system, optical resolution of D/L-phenylalanine analogs was performed. The D-phenylalanine analogs were obtained efficiently with high optical purity [60].

\subsection{C-C Bond Formation, Condensation and Addition}

Processing with $\mathrm{C}-\mathrm{C}$ bond formation, condensation and addition reactions performed in a microchannel system are shown in Table 5.

Table 5. Processing with $\mathrm{C}-\mathrm{C}$ bond formation, condensation and addition.

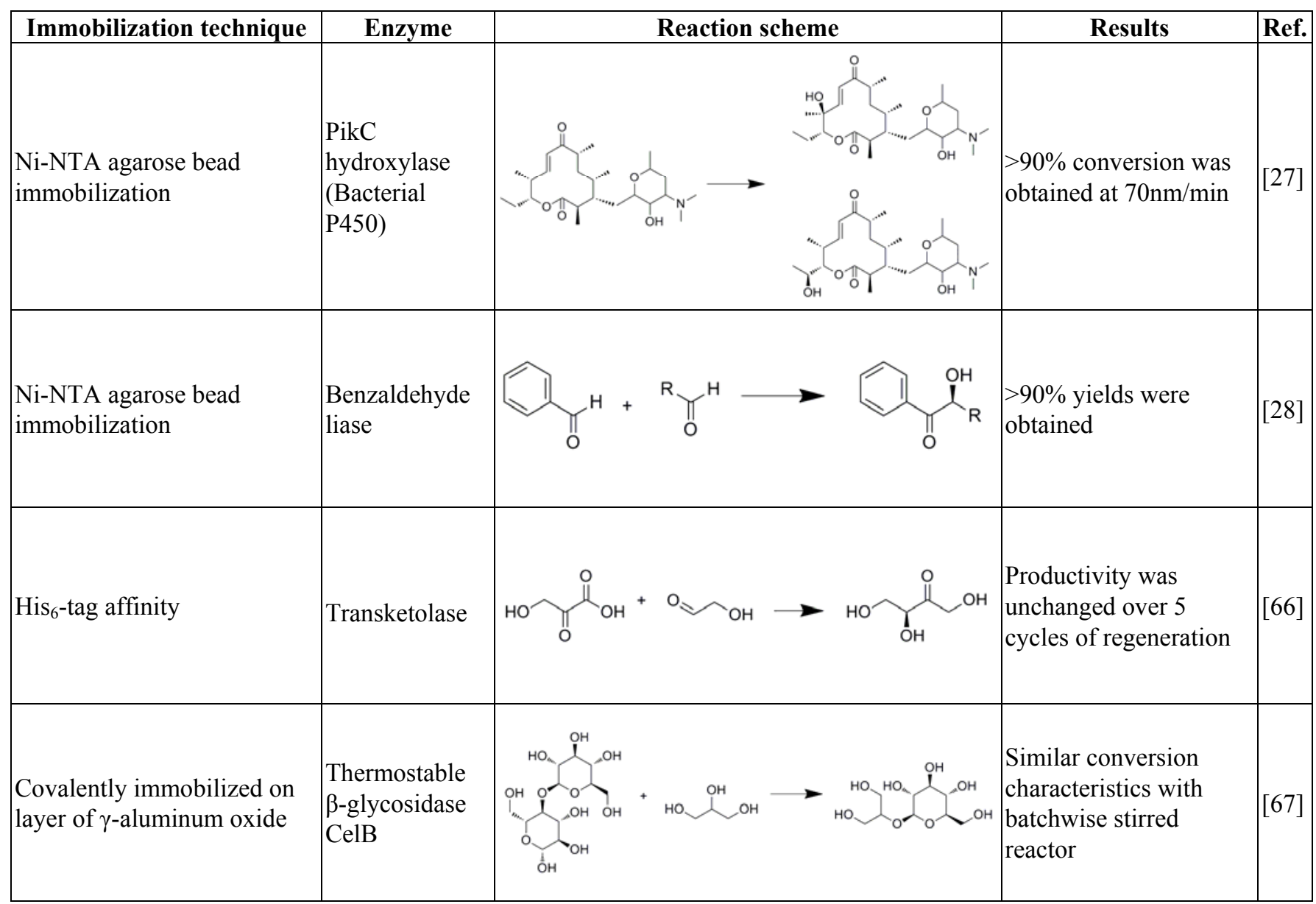

Hydroxylation of macrolides in a microreactor was reported [27]. PikC Hydroxylase was immobilized on Ni-NTA agarose beads, and then filled into the microchannel. This microreactor was used for hydroxylation to produce methymycin and neomethymycin, and over $90 \%$ conversion was achieved at a flow rate of $70 \mathrm{~nL} / \mathrm{min}$. Such high efficiency might have resulted from the shorter residence time, which is preferable for enzymes with inherent stability. Similar immobilization 
technique was applied for the synthesis of $(R)$-benzoin using benzaldehyde lyase [28]. His-tagged protein was directly immobilized within the microstructured PASSflow reaction system through tyrosine-based Ni-NTA system. This reversible immobilization technique was also used for transketolase, which catalyses the synthesis of L-erythrulose [66]. Its productivity was unchanged over five regeneration cycles. Schwarz et al. reported transglycosilation using cellobiose and glycerol to produce $\beta$-glycosylglycerol [67]. The enzyme was immobilized onto the $\gamma$-alumina layer formed within a microchannel. However, the resulting microreactor showed almost similar conversion characteristics as the batchwise reaction.

\subsection{Oxidation and Reduction}

The application of enzyme-immobilized microreactors for oxidation and reduction was also reported (Table 6). Although the uses of oxidation reactions with the enzyme-immobilization techniques were mainly for analytical use, the oxidation of phenols with a horseradish peroxidaseimmobilized microreactor was recently reported [68].

Table 6. Oxidation, reduction and miscellaneous reactions in enzyme-immobilized microreactor.

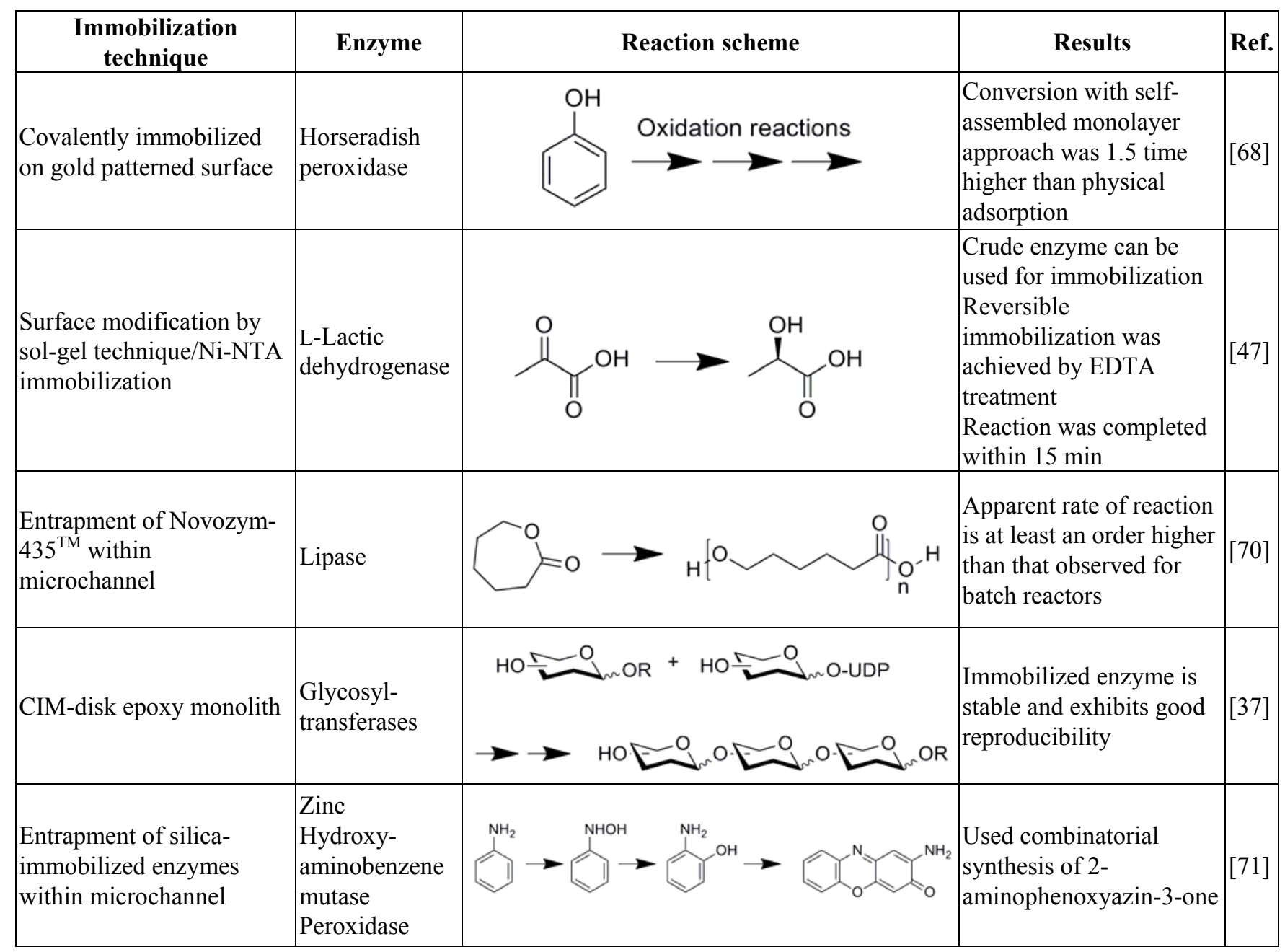

We demonstrated the reduction of pyruvic acid to produce L-lactic acid by L-lactic dehydrogenase immobilized on microchannel surface through Ni-NTA group formed by sol-gel technique [47]. By 
this method, crude enzyme extract from bacterial lysed solution could be used for immobilization without further purification. Also, reversible immobilization was enabled to regenerate the microreactor upon enzyme denaturation. This reactor showed higher conversion rates than that of the batchwise reaction; however regeneration of co-enzyme still remains a major problem in this case. Yoon et al. reported an electrochemical microreactor for regeneration of coenzymes [69]. However, they used solution-phase reactions using enzyme solutions. Integration of enzyme immobilization techniques with this microreactor for co-enzyme regeneration might solve this problem.

\subsection{Miscellaneous Reactions}

Enzymatic polymerization has been performed in microfluidic format. Entrapped Novozym- $435^{\mathrm{TM}}$ was used for ring-opening polymerization of $\varepsilon$-caprolactone to produce polycaprolactone [70]. The microreactor showed improved reaction rates, higher than those observed in the batchwise reaction. Glycosyltransferase-entrapped monolith was used for the preparation of oligosaccharides from monosaccharides [37]. The immobilized enzyme was stable and the resulting microreactor exhibited good reproducibility.

The application of enzyme-immobilized microreactors for multistep synthesis was also demonstrated [71]. Three separate microfluidic devices, which possesed metallic zinc, silica-immobilized hydroxyaminobenzene mutase, and silica-immobilized peroxidase within a microchannel, were prepared and connected sequentially. These devices were used for combinatorial synthesis of 2-aminophenoxyazin-3-ones. These results open the door for the application of micro bioreactors for the enzymatic synthesis of bioactive natural products.

\section{Conclusions}

Microchannel devices can be useful in imitating biological reaction apparatus, such as cellular surfaces and vascular systems, by providing the advantages of limited space and laminar flow compared with the conventional reaction apparatus. The quest for microreaction technologies will lead to better process intensification and efficient analytical methods. Increasingly, new findings are being achieved in microfluidics. Further investigation on microfluidics could provide novel mechanisms not observed in conventional systems, and better understanding of fluidics in microchannels might enable new reaction pathways not possible with conventional systems.

The strong advantages offered by microreaction devices are useful, particularly in the development of microreaction systems for commercial purposes. Once a microreactor is optimized, it can be easily introduced into an industrial-scale plant. Parallel scale-out enables extension of reaction conditions optimized in a single reactor, and eliminates scale-up problems arising from conventional processes. Parallel operation of the same microreaction provides high throughput operation of different reagents at a single operation and serves as an excellent tool for combinatorial processing. Although several problems, such as connection, parallel control of fluid and reaction conditions, and monitoring, are common challenges, the benefits offered by microreaction technology accelerate the development of enzyme reaction devices.

As described here, few enzymes have been applied for microreaction process development, and not many patents describing the construction of micro enzyme reactors are published. These facts are an 
indication that the field is still in its initial stages. Efforts directed to the development, optimization and application of micro enzyme reactors will open a new era for biochemical processing in the synthetic organic chemistry field.

\section{Acknowledgements}

This work was supported by Grant-in-Aid for Basic Scientific Research (B: 23310092) and for Young Scientists (B: 23710153), from the Japan Society for the Promotion of Science (JSPS).

\section{References}

1. Ehrfeld, W.; Hessel, V.; Lowe, H. Microreactors-New Technology for Modern Chemistry; Wiley-VCH: Weinheim, Germany, 2000.

2. Székely, L.; Guttman, A. New advances in microchip fabrication for electrochromatography. Electrophoresis 2005, 26, 4590-4604.

3. Ziaie, B.; Baldia, A.; Leia, M.; Guc, Y.; Siegelb, R.A. Hard and soft micromachining for BioMEMS: Review of techniques and examples of applications in microfluidics and drug delivery. Adv. Drug Delivery Rev. 2004, 56, 145-172.

4. Hessel, V.; Hardt, S.; Lowe, H. Chemical Micro Process Engineering; Wiley-VCH: Weinheim, Germany, 2004.

5. Watts, P.; Haswell, S.J. The application of micro reactors for organic synthesis. Chem. Soc. Rev. 2005, 34, 235-246.

6. Chován, T.; Guttman, A. Microfabricated devices in biotechnology and biochemical processing. Trends Biotechnol. 2002, 20, 116-122.

7. Andersson, H.; van den Berg, A. Microfluidic devices for cellomics: A review. Sens. Actuat. B 2003, 92, 315-325.

8. Cullen, C.J.; Wootton, R.C.; De Mello, A.J. Microfluidic systems for high-throughput and combinatorial chemistry. Curr. Opin. Drug Discov. Dev. 2004, 7, 798-806.

9. Wang, H.; Holladay, J.D. Microreactor Technology and Process Intensification, ACS Symposium Series, Vol. 914; American Chemical Society: Washington, DC, USA, 2005.

10. Miyazaki, M.; Maeda, H. Microchannel enzyme reactors and their applications for processing. Trends Biotechnol. 2006, 24, 463-470.

11. Schoemaker, H.E.; Mink, D.; Wubbolts, M.G. Dispelling the myths-biocatalysis in industrial synthesis. Science 2003, 299, 1694-1697.

12. García-Junceda, E.; García-García, J.F.; Bastida, A.; Fernández-Mayoralas, A. Enzymes in the synthesis of bioactive compounds: The prodigious decades. Bioorg. Med. Chem. 2004, 12, 1817-1834.

13. Schmid, A.; Dordick, J.S.; Hauer, B.; Kiener, A.; Wubbolts, M.; Witholt, B. Industrial biocatalysis today and tomorrow. Nature 2001, 409, 258-268.

14. Urban, P.L.; Goodall, D.M.; Bruce, N.C. Enzymatic microreactors in chemical analysis and kinetic studies. Biotechnol. Adv. 2006, 24, 42-57. 
15. Tokeshi, M.; Minagawa, T.; Uchiyama, K.; Hibara, A.; Sato, K.; Hisamoto, H.; Kitamori, T. Continuous-flow chemical processing on a microchip by combining microunit operations and a multiphase flow network. Anal. Chem. 2002, 74, 1565-1571.

16. Hibara, A.; Nonaka, M.; Hisamoto, H.; Uchiyama, K.; Kikutani, Y.; Tokeshi, M.; Kitamori, T. Stabilization of liquid interface and control of two-phase confluence and separation in glass microchips by utilizing octadecylsilane modification of microchannels. Anal. Chem. 2002, 74, 1724-1728.

17. Zhao, B.; Moore, J.S.; Beebe, D.J. Principles of surface-directed liquid flow in microfluidic channels. Anal. Chem. 2002, 74, 4259-4268.

18. Yamaguchi, Y.; Ogino, K.; Takagi, F.; Honda, T.; Yamashita, K.; Miyazaki, M.; Nakamura, H.; Maeda, H. Partial Chemical Modification of a Microchannel and Stabilization of Water-Oil Phase Separation. In Proceedings of the 8th International Conference on Microreaction Technology (IMRET 8), Atlanta, GA, USA, 10-14 April 2005; American Institute of Chemical Engineers: New York, NY, USA, 2005.

19. Erickson, D.; Li, D. Influence of surface heterogeneity on electrokinetically driven microfluidic mixing. Langmuir 2002, 18, 1883-1892.

20. Seong, G.H.; Crooks, R.M. Efficient mixing and reactions within microfluidic channels using microbead-supported catalysts. J. Am. Chem. Soc. 2002, 124, 13360-13361.

21. Stroock, A.D.; Dertinger, S.K.W.; Ajdari, A.; Mezic, I.; Stone, H.A.; Whitesides, G.M. Chaotic mixer for microchannels. Science 2002, 295, 647-651.

22. Kim, J.-H.; Kin, B.-G.; La, M.; Yoon, J.-B.; Yoon, E. A Disposable Passive Microfluidic System Integrated with Micromixer and DNA Purification Chip for DNA Sample Preparation. In Micro Total Analysis System 2002; Baba, Y., Shoji, S., van den Berg, A., Eds.; Kluwer Academic Publishers: Dordrecht, The Netherlands, 2002; Volume 1, pp. 224-226.

23. Mengeaud, V.; Josserand, J.; Girault, H.H. Mixing processes in a zigzag microchannel: finite element simulations and optical study. Anal. Chem. 2002, 74, 4279-4286.

24. Yamaguchi, Y.; Ogino, K.; Yamashita, K.; Maeda, H. Rapid micromixing based on multilayer laminar flows. J. Chem. Eng. Jpn. 2004, 37, 1265-1270.

25. Chang, C.-C.; Yang, R.-J. Electrokinetic mixing in microfluidic systems. Microfluid. Nanofluid. 2007, 3, 501-525.

26. Richter, T.; Shultz-Lockyear, L.L.; Oleschuk, R.D.; Bilitewski, U.; Harrison, D.J. Bi-enzymatic and capillary electrophoretic analysis of non-fluorescent compounds in microfluidic devices determination of Xanthine. Sens. Actuat. B 2002, 81, 369-376.

27. Srinivasan, A.; Bach, H.; Sherman, D.H.; Dordick, J.S. Bacterial P450-catalyzed polyketide hydroxylation on a microfluidic platform. Biotechnol. Bioeng. 2004, 88, 528-535.

28. Dräger, G.; Kiss, C.; Kunz, U.; Kirschning, A. Enzyme-purification and catalytic transformations in a microstructured PASSflow reactor using a new tyrosine-based Ni-NTA linker system attached to a polyvinylpyrrolidinone-based matrix. Org. Biomol. Chem. 2007, 5, 3657-3664.

29. Nomura, A.; Shin, S.; Mehdi, O.O.; Kauffmann, J.-M. Preparation, characterization, and application of an enzyme-immobilized magnetic microreactor for flow injection analysis. Anal.

Chem. 2004, 76, 5498-5502. 
30. Li, Y.; Xu, X.; Yan, B.; Deng, C.; Yu, W.; Yang, P.; Zhang, X. Microchip reactor packed with metal-ion chelated magnetic silica microspheres for highly efficient proteolysis. J. Proteome Res. 2007, 6, 2367-2375.

31. Sakai-Kato, K.; Kato, M.; Ishihara, K.; Toyo'oka, T. An enzyme-immobilization method for integration of biofunctions on a microchip using a water-soluble amphiphilic phospholipid polymer having a reacting group. Lab Chip 2004, 4, 4-6.

32. Sakai-Kato, K.; Kato, M.; Toyo'oka, T. Creation of an on-chip enzyme reactor by encapsulating trypsin in sol-gel on a plastic microchip. Anal. Chem. 2003, 75, 388-393.

33. Kawakami, K.; Sera, Y.; Sakai, S.; Ono, T.; Ijima, H. Development and characterization of a silica monolith immobilized enzyme micro-bioreactor. Ind. Eng. Chem. Res. 2005, 44, 236-240.

34. Heule, M.; Rezwan, K.; Cavalli, L.; Gauckler, L.J. A miniaturized enzyme reactor based on hierarchically shaped porous ceramic microstruts. Adv. Mater. 2003, 15, 1191-1194.

35. Kawakami, K.; Abe, D.; Urakawa, T.; Kawashima, A.; Oda, Y.; Takahashi, R.; Sakai, S. Development of a silica monolith microbioreactor entrapping highly activated lipase and an experiment toward integration with chromatographic separation of chiral esters. J. Sep. Sci. 2007, 30, 3077-3084.

36. Krenkova, J.; Lacher, N.A.; Svec, F. Highly efficient enzyme reactors containing trypsin and endoproteinase LysC immobilized on porous polymer monolith coupled to MS suitable for analysis of antibodies. Anal. Chem. 2009, 81, 2004-2012.

37. Delattre, C.; Vijayalakshmi, M.A. Monolith enzymatic microreactor at the frontier of glycomic toward a new route for the production of bioactive oligosaccharides. J. Mol. Catal. B 2009, 60, 97-105.

38. Yang, C.; Zhang, Z.; Shi, Z.; Xue, P.; Chang, P.; Yan, R. Development of a novel enzyme reactor and application as a chemiluminescence flow-through biosensor. Anal. Bioanal. Chem. 2010, 397, 2997-3003.

39. Baeza, M.; López, C.; Alonso, J.; López-Santín, J.; Alvaro, G. Ceramic microsystem incorporating a microreactor with immobilized biocatalyst for enzymatic spectrophotometric assays. Anal. Chem. 2010, 82, 1006-1011.

40. Gleason, N.J.; Carbeck, J.D. Measurement of enzyme kinetics using microscale steady-state kinetic analysis. Langmuir 2004, 20, 6374-6381.

41. Mao, H.; Yang, T.; Cremer, P.S. Design and characterization of immobilized enzymes in microfluidic systems. Anal. Chem. 2002, 74, 379-385.

42. Holden, M.A.; Jung, S.-Y.; Cremer, P.S. Patterning enzymes inside microfluidic channels via photoattachment chemistry. Anal. Chem. 2004, 76, 1838-1843.

43. Ekström, S.; Onnerfjord, P.; Nilsson, J.; Bengtsson, M.; Laurell, T.; Marko-Varga, G. Integrated microanalytical technology enabling rapid and automated protein identification. Anal. Chem. 2000, 72, 286-293.

44. Miyazaki, M.; Kaneno, J.; Uehara, M.; Fujii, M.; Shimizu, H.; Maeda, H. Simple method for preparation of nanostructure on microchannel surface and its usage for enzyme-immobilization. Chem. Commun. 2003, 648-649.

45. Kaneno, J.; Kohama, R.; Miyazaki, M.; Uehara, M.; Kanno, K.; Fujii, M.; Shimizu, H.; Maeda, H. A simple method for surface modification of microchannels. New J. Chem. 2003, 27, 1765-1768. 
46. Miyazaki, M.; Kaneno, J.; Kohama, R.; Uehara, M.; Kanno, K.; Fujii, M.; Shimizu, H.; Maeda, H. Preparation of functionalized nanostructures on microchannel surface and their use for enzyme microreactors. Chem. Eng. J. 2004, 101, 277-284.

47. Miyazaki, M.; Kaneno, J.; Yamaori, S.; Honda, T.; Briones, M.P.P.; Uehara, M.; Arima; K.; Kanno, K.; Yamashita, K.; Yamaguchi, Y.; et al. Efficient immobilization of enzymes on microchannel surface through His-tag and application for microreactor. Protein Pept. Lett. 2005, $12,207-210$.

48. Qu, H.; Wang, H.; Huang, Y.; Zhong, W.; Lu, H.; Kong, J.; Yang, P.; Liu, B. Stable microstructured network for protein patterning on a plastic microfluidic channel: Strategy and characterization of on-chip enzyme microreactors. Anal. Chem. 2004, 76, 6426-6433.

49. Wu, H.; Tian, Y.; Liu, B.; Lu, H.; Wang, X.; Zhai, J.; Jin, H.; Yang, P.; Xu, Y.; Wang, H. Titania and alumina sol-gel-derived microfluidics enzymatic-reactors for peptide mapping: Design, characterization, and performance. J. Proteome Res. 2004, 3, 1201-1209.

50. Ji, J.; Zhang, Y.; Zhou, X.; Kong, J.; Tang, Y.; Liu, B. Enhanced protein digestion through the confinement of nanozeolite-assembled microchip reactors. Anal. Chem. 2008, 80, 2457-2463.

51. Thomsen, M.S.; Pölt, P.; Nidetzky, B. Development of a microfluidic immobilised enzyme reactor. Chem. Commun. 2007, 2527-2529.

52. Nakamura, H.; Li, X.; Wang, H.; Uehara, M.; Miyazaki, M.; Shimizu, H.; Maeda, H. A simple method of self assembled nano-particles deposition on the micro-capillary inner walls and the reactor application for photo-catalytic and enzyme reactions. Chem. Eng. J. 2004, 101, 261-268.

53. Schilke, K.F.; Wilson, K.L.; Cantrell, T.; Corti, G.; McIlroy, D.N.; Kelly, C. A novel enzymatic microreactor with Aspergillus oryzae $\beta$-galactosidase immobilized on silicon dioxide nanosprings. Biotechnol. Prog. 2010, 26, 1597-1605.

54. Logan, T.C.; Clark, D.S.; Stachowiak, T.B.; Svec, F.; Fréchet, J.M.J. Photopatterning enzymes on polymer monoliths in microfluidic devices for steady-state kinetic analysis and spatially separated multi-enzyme reactions. Anal. Chem. 2007, 79, 6592-6598.

55. Koh, W.; Pishko, M. Immobilization of multi-enzyme microreactors inside microfluidic devices. Sens. Actuat. B 2005, 106, 335-342.

56. Gao, J.; Xu, J.; Locascio, L.E.; Lee, C.S. Integrated microfluidic system enabling protein digestion, peptide separation, and protein identification. Anal. Chem. 2001, 73, 2648-2655.

57. Hisamoto, H.; Shimizu, Y.; Uchiyama, K.; Tokeshi, M.; Kikutani, Y.; Hibara, A.; Kitamori, T. Chemicofunctional membrane for integrated chemical processes on a microchip. Anal. Chem. 2003, 75, 350-354.

58. Honda, T.; Miyazaki, M.; Nakamura, H.; Maeda, H. Immobilization of enzymes on a microchannel surface through cross-linking polymerization. Chem. Commun. 2005, 5062-5064.

59. Honda, T.; Miyazaki, M.; Nakamura, H.; Maeda, H. Facile preparation of an enzyme-immobilized microreactor using a cross-linking enzyme membrane on a microchannel surface. Adv. Synth. Catal. 2006, 348, 2163-2171.

60. Honda, T.; Miyazaki, M.; Yamaguchi, Y.; Nakamura, H.; Maeda, H. Integrated microreaction system for optical resolution of racemic amino acids. Lab Chip 2007, 7, 366-372.

61. Wang, H.; Li, X.; Nakamura, H.; Miyazaki, M.; Maeda, H. Continuous particle self-arrangement in a long micro-capillary. Adv. Mater. 2002, 14, 1662-1666. 
62. Cao, L.; Langen, L.V.; Sheldon, R.A. Immobilised enzymes: carrier-bound or carrier-free? Curr. Opin. Biotechnol. 2003, 14, 387-394.

63. Matsuura, S.; Ishii, R.; Itoh, T.; Hamakawa, S.; Tsunoda, T.; Hanaoka, T.; Mizukami, F. Immobilization of enzyme-encapsulated nanoporous material in a microreactor and reaction analysis. Chem. Eng. J. 2011, 167, 744-749.

64. Anuar, S.T.; Villegas, C.; Mugo, S.M.; Curtis, J.M. The development of flow-through bio-catalyst microreactors from silica micro structured fibers for lipid transformations. Lipids 2011, 46, 545-555.

65. Garcia, E.; Ferrari, F.; Garcia, T.; Martinez, M.; Aracil, J. Use of Microreactors in Biotransformation Processes: Study of the Synthesis of Diglycerol Monolaurate Ester. In Proceedings of the 4th International Conference on Microreaction Technology (IMRET 4), Atlanta, GA, USA, 5-9 March 2000; American Institute of Chemical Engineers: New York, NY, USA, 2000; pp. 5-9.

66. Matosevic, S.; Lye, G.J.; Baganz, F. Design and characterization of a prototype enzyme microreactor: Quantification of immobilized transketolase kinetics. Biotechnol. Prog. 2010, 26, 118-126.

67. Schwarz, A.; Thomsen, M.S.; Nidetzky, B. Enzymatic synthesis of $\beta$-glucosylglycerol using a continuous-flow microreactor containing thermostable $\beta$-glycoside hydrolase CelB immobilized on coated microchannel walls. Biotechnol. Bioeng. 2009, 103, 865-872.

68. Tudorache, M.; Mahalu, D.; Teodorescu, C.; Stan, R.; Bala, C.; Parvulescu, V.I. Biocatalytic microreactor incorporating HRP anchored on micro-/nano-lithographic patterns for flow oxidation of phenols. J. Mol. Catal. B 2011, 69, 133-139.

69. Yoon, S.K.; Choban, E.R.; Kane, C.; Tzedakis, T.; Kenis, P.J. a Laminar flow-based electrochemical microreactor for efficient regeneration of nicotinamide cofactors for biocatalysis. J. Am. Chem. Soc. 2005, 127, 10466-10467.

70. Kundu, S.; Bhangale, A.S.; Wallace, W.E.; Flynn, K.M.; Guttman, C.M.; Gross, R.A.; Beers, K.L. Continuous Flow Enzyme-Catalyzed Polymerization in a Microreactor. J. Am. Chem. Soc. 2011, 6006-6011.

71. Luckarift, H.R.; Ku, B.S.; Dordick, J.S.; Spain, J.C. Silica-immobilized enzymes for multi-step synthesis in microfluidic devices. Biotechnol. Bioeng. 2007, 98, 701-705.

(C) 2011 by the authors; licensee MDPI, Basel, Switzerland. This article is an open access article distributed under the terms and conditions of the Creative Commons Attribution license (http://creativecommons.org/licenses/by/3.0/). 